\title{
Carol C. Kuhlthau - Interviewed at the Conference Learning, Innovation and the Use of Information in Aalborg, Denmark, April 2008
}

\author{
Anne Sissel Vedvik Tonning \\ University of Bergen
}

\section{INTERVIEW}

Librarians have to stop using time and energy on legitimising our position, and rather use the resources to develop librarianship to support our users in their work with information to create knowledge, says Kuhlthau in the interview. She further states that "The library in the information age is the centrepiece of the reformed school".

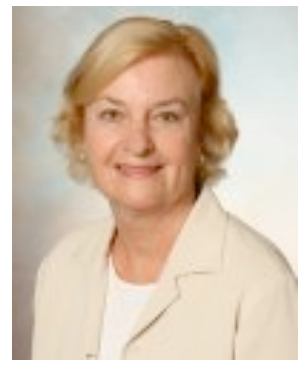

Carol C.

Kuhlthau

- How do you think the librarian's role has changed during the last decades?

- When I got into librarianship and particularly in the research that I did, I could see that the librarian who only provides information sources was not sufficient to move the students to where they wanted to be in using those sources. There was the librarian on the one hand providing the resources and the sources of information, all the books and the materials, and on the other hand there was the teacher or the assignment. But there wasn't anything in between enabling the student to use that information. And that is the work my research is about, and I became so convinced that that had to be explored, for the librarian and for library services to meet users' needs. Because the users were struggling; and even more so now, as I've I found over the past ten years in particular. The amount of information that's available to people in their own home, in their own dorm-room, in the computer in the library, the amount of information that's available to them, just bombarding them, makes it more difficult rather than easier for them to be able to accomplish a task, although you would think it was the opposite. Indeed the user too thinks it's the opposite. So that's where I see the librarianship as being in a time of change. The librarian is moving from something very structured to something that's much less structured, working with ideas and concepts, pulling in resources and working with the person who is going through various different stages of a problem. But I don't think we're quite there yet. It is a hugely changing profession. 
- The Ohio Study (Todd \& Kuhlthau, 2005) was a study of what students from primary to highschool levels thought of their school library. What were your most important conclusions from this study?

- What that study showed, at least for me, more than anything else, was that we librarians tend to think that we have to justify our library services, that we have to constantly say "well we're here because we're good, because we're doing good work" and we constantly think we have to prove ourselves. But only $1 \%$ of the respondents did not agree that the library is "very important to me, helps me in my school work, helps me to do better in my courses and helps me to get better grades". That study showed that the students just assumed that we were there for them; they just assumed we would help them. And so it wasn't as though we had to say, "yes we're good, yes we're helping you". And I think that we spend a lot of time in librarianship trying to justify our position rather than just getting on with the good work that we do and exploring and creating; that new kind of work that is so essential not only for students, but for people in the work world and for people in their personal lives too.

- In our new journal, NORIL, we want to focus on teaching and learning information literacy in higher education, and that of course also applies to teacher training education. Today we have to start our information literacy programmes at a very basic level which, in my opinion, should be among the students' acquired competencies before entering higher education. And to change this we have to look at the teacher training curriculum; because systematic teaching and learning information literacy from primary to high school will give the students in higher education much more interesting information literacy courses, tailored to their level and subject assignments. I think the teacher training curriculum should include courses in how to use the school library in their own teaching during their "practicum" period. Do you have some comments on that?

- Actually, this is close to the work that I've been doing most recently. I decided that I would write a book* with a teacher and a museum educator... both happened to be my daughters! The teacher has a $\mathrm{PhD}$ in curriculum and is a reading specialist and the museum educator works with using museum artefacts and collections for inquiry learning. The book is written for the whole team; for librarians (though not specifically from the librarian's point of view); for teachers; for administrators; and for all other people in the school who are experts, and who can bring a lot of knowledge and expertise to that inquiry task that the students are involved with. Some call this project-based learning which is the same idea. We are trying to reform schools, to transform education and create new models; and the one piece that's missing over and over again in these models to reform schools or studies is the library. The library in the information age is the centrepiece of the reformed school. And so that's what this book is about. It's a foundational book that explains how the library is a central part of a team that works together in this project-based approach that enables students to learn how to use information not just for understanding their own ideas, but also for solving problems and for creating new ways of looking at things. So I think the way to go in the schools of education is if a book like this actually could be taken into a teacher preparation course. It would be very appropriate for a teacher education course as well as for library education courses.

\section{References}

*Kuhlthau, C.C., Caspari, A.K. \& Maniotes, L. (2007). Guided Inquiry. Learning in the 21st Century. Westport, Conn. : Libraries Unlimited

Todd, R. \& Kuhlthau, C.C. (2005). Student Learning Through Ohio School Libraries, Part I+II. School Libraries Worldwide, 11(1), 63-110 